NBER WORKING PAPER SERIES

THE ECONOMIC COST OF GLOBAL FUEL SUBSIDIES

\author{
Lucas W. Davis \\ Working Paper 19736 \\ http://www.nber.org/papers/w19736 \\ NATIONAL BUREAU OF ECONOMIC RESEARCH \\ 1050 Massachusetts Avenue \\ Cambridge, MA 02138 \\ December 2013
}

I am grateful to Judson Boomhower, Severin Borenstein, Gilbert Metcalf and Catherine Wolfram for helpful comments. I have not received any financial compensation for this project nor do I have any financial relationships that relate to this research. The views expressed herein are those of the author and do not necessarily reflect the views of the National Bureau of Economic Research.

NBER working papers are circulated for discussion and comment purposes. They have not been peerreviewed or been subject to the review by the NBER Board of Directors that accompanies official NBER publications.

(C) 2013 by Lucas W. Davis. All rights reserved. Short sections of text, not to exceed two paragraphs, may be quoted without explicit permission provided that full credit, including $\odot$ notice, is given to the source. 
The Economic Cost of Global Fuel Subsidies

Lucas W. Davis

NBER Working Paper No. 19736

December 2013

JEL No. H23,Q41,Q48,Q51

\section{$\underline{\text { ABSTRACT }}$}

By 2015, global oil consumption will reach 90 million barrels per day. In part, this high level of consumption reflects the fact that many countries provide subsidies for gasoline and diesel. This paper examines global fuel subsidies using the latest available data from the World Bank, finding that road-sector subsidies for gasoline and diesel totaled $\$ 110$ billion in 2012. Pricing fuels below cost is inefficient because it leads to overconsumption. Under baseline assumptions about supply and demand elasticities, the total annual deadweight loss worldwide is $\$ 44$ billion. Incorporating external costs increases the economic costs substantially.

Lucas W. Davis

Haas School of Business

University of California

Berkeley, CA 94720-1900

and NBER

ldavis@haas.berkeley.edu 


\title{
The Economic Cost of Global Fuel Subsidies
}

\author{
Lucas W. Davis*
}

December 2013

By 2015, global oil consumption will reach 90 million barrels per day. ${ }^{1}$ In part, this high level of consumption reflects the fact that many countries provide subsidies for gasoline and diesel. This paper examines global fuel subsidies using the latest available data from the World Bank, finding that road-sector subsidies for gasoline and diesel totaled $\$ 110$ billion in 2012 . Pricing fuels below cost is inefficient because it leads to overconsumption. Under baseline assumptions about supply and demand elasticities, the total annual deadweight loss worldwide is $\$ 44$ billion. Incorporating external costs increases the economic costs substantially.

\section{Fuel Prices}

Figure 1 plots road-sector gasoline consumption per capita and gasoline prices for 128 countries. A plot of diesel consumption and prices is available in the online appendix. Prices are domestic consumer prices including taxes and come from a survey administered November 2012. The size of the circles is proportional to country population.

The figure reveals an enormous amount of variation in gasoline prices. Gasoline prices average $\$ 5.26$ per gallon, but range from $\$ .09$ per gallon in Venezuela to above $\$ 9.00$ in Turkey and Norway. Diesel prices tend to be a bit lower, averaging $\$ 4.12$ per gallon, with a range from $\$ .04$ to above $\$ 7.00$.

\footnotetext{
${ }^{*}$ Haas School of Business, University of California, Berkeley, CA 94720; Energy Institute at Haas; and National Bureau of Economic Research. Email: ldavis@haas.berkeley.edu. I am grateful to Judson Boomhower, Severin Borenstein, Gilbert Metcalf and Catherine Wolfram for helpful comments. I have not received any financial compensation for this project nor do I have any financial relationships that relate to this research.

${ }^{1}$ U.S. DOE (2013A), Table A5.
} 


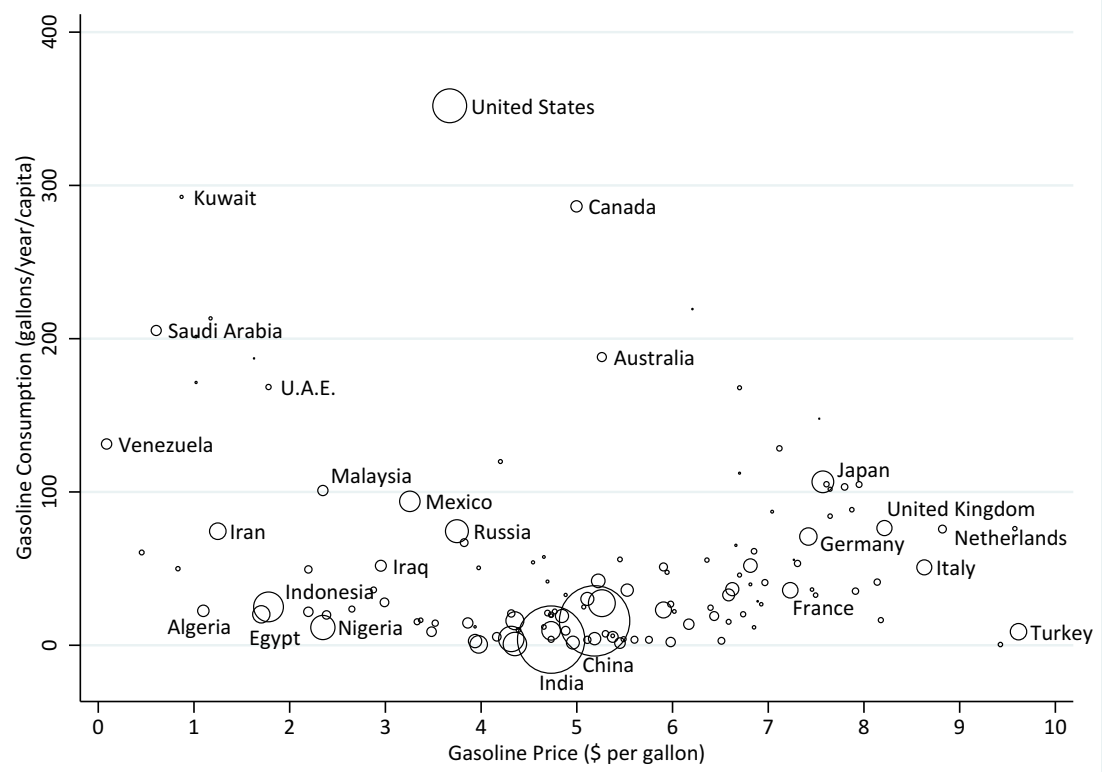

Figure 1: Gasoline Consumption and Prices Worldwide

This wide variation in prices is somewhat surprising because crude oil and refined products are widely traded internationally, so the opportunity cost of fuels is similar everywhere. Although there are differences in transportation, refining, and distribution costs, they can explain only a small part of the observed variation in prices.

Instead, the more important explanation for the wide variation in fuel prices is that taxes and subsidies differ widely. Among OECD countries, gasoline taxes per gallon range from an average of $\$ 0.49$ in the United States, to above $\$ 4.00$ in Germany and the Netherlands (Knittel, 2012). Outside the OECD the range is even larger, and there are dozens of countries that subsidize gasoline and diesel, selling it for below its price in international markets. Many of these countries are in the Middle East, though Asia (Malaysia, Indonesia), Africa (Egypt, Nigeria, Algeria) and South America (Venezuela, Ecuador, Bolivia) are also represented.

Gasoline consumption tends to be high in countries where gasoline is 
subsidized. Saudi Arabia, for example, has experienced a nine-fold increase in fuels consumption since 1971 and is now the sixth largest oil consumer in the world (Gately et al., 2012). Venezuela is another particularly illustrative example. Gasoline consumption per capita in Venezuela is $40 \%$ higher than in any other country in Latin America, and more than three times the regional average.

Figure 2 shows the countries with the largest fuel subsidies. The implied subsidy per gallon was calculated as the difference between domestic consumer prices and international spot prices. Transport, distribution, and retailing costs were incorporated following IMF (2013). The implied subsidy per gallon was then multiplied by road-sector consumption of each fuel to calculate the total dollar value. By this measure, there are 24 countries that subsidize gasoline, and 35 countries that subsidize diesel. The United States, by this measure, does not subsidize gasoline or diesel. ${ }^{2}$

Total subsidies worldwide in 2012 were $\$ 110$ billion, with about $\$ 55$ billion each for gasoline and diesel. The top ten countries represent $90 \%$ of total global subsidies. Many of these countries are major oil producers. Fuel subsidies have long been viewed in many oil-producing countries as a way to share the resource wealth with a nation's citizens. This is not the view in all major oil-producing countries, however. Prices are at or above market in Iraq ( $\$ 2.95$ per gallon for gasoline), Mexico $(\$ 3.26)$, Russia $(\$ 3.74)$, and Canada $(\$ 5.00)$.

The following section calculates the deadweight loss from these fuel subsidies. This focus on countries with low fuel prices is somewhat arbitrary. Just as there is deadweight loss from prices that are too low, there is also deadweight loss from prices that are too high. The United Kingdom ( $\$ 8.21$ per gallon), Italy (\$8.63), Netherlands $(\$ 8.82)$, and Turkey $(\$ 9.61)$, for example, would all seem to be possible candidates. While it is true that traffic congestion and other external costs vary substantially across locations, these

\footnotetext{
${ }^{2}$ This measure of fuel subsidies captures consumption subsidies but not production subsidies. Aldy (2013) reports that U.S. oil, gas, and coal producers receive $\$ 4$ billion annually in tax deductions, favorable depreciation schedules, and other production subsidies. Because there is a world oil market, production subsidies have almost no impact on consumer prices.
} 


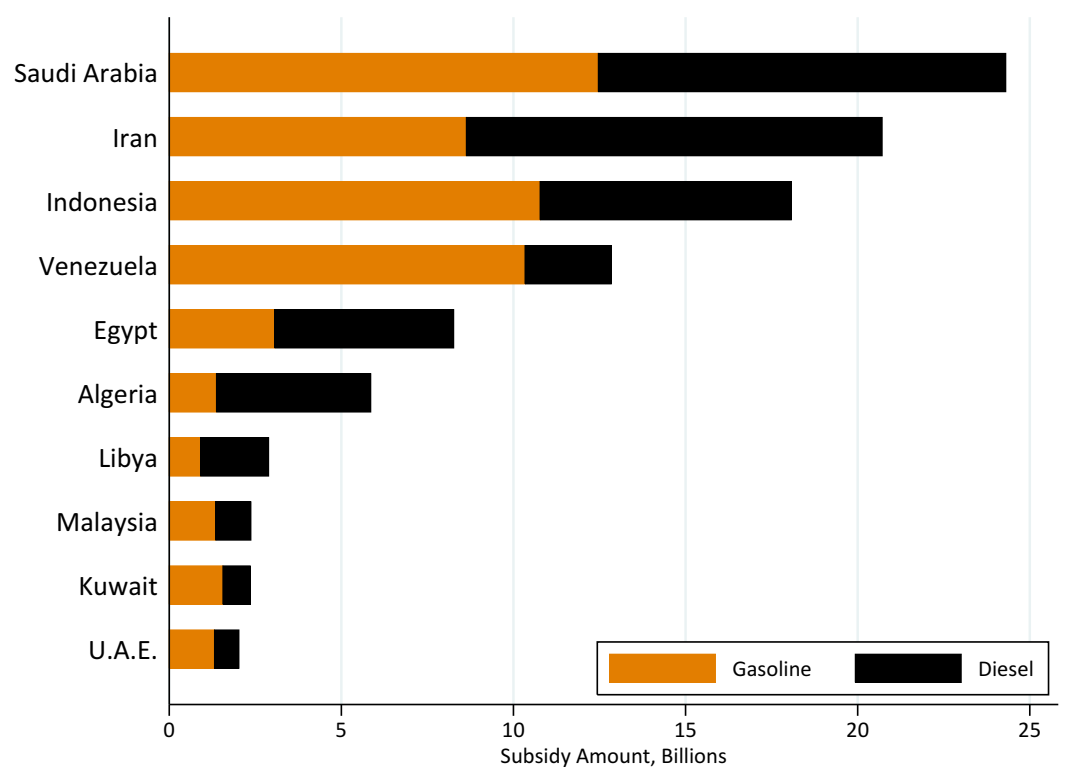

Figure 2: Dollar Value of Fuel Subsidies in 2012, Top Ten Countries

countries have prices that are high enough that it becomes difficult to justify on the basis of externalities (Parry and Small, 2005). Governments with both low and high prices are presumably pursuing some objective (e.g. redistribution, revenue collection, etc.) but these goals must be weighed against the distortions that are imposed.

\section{Deadweight Loss}

Subsidies create deadweight loss by enabling transactions for which the buyer's willingness-to-pay is below the opportunity cost. The total amount of deadweight loss depends on the elasticities of demand and supply. The more elastic are demand and supply, the larger the deadweight loss from pricing below cost. In the short-run, demand and supply for crude oil are both inelastic (Hamilton, 2009). However, the economic cost of subsidies depends on the long-run elasticities. Estimates in the literature for the 
long-run elasticity of demand for transportation fuels tend to range from -0.6 to -0.8 (Brons et al., 2008). The analysis which follows adopts -0.6. Total global deadweight loss is $18 \%$ higher when -0.8 is used instead.

Demand is described using a constant elasticity demand function with a scale parameter that varies across countries and fuels. As described in the online appendix, current prices and consumption levels are first used to calculate the complete set of scale parameters. These demand functions are then used to predict consumption at market prices and to calculate deadweight loss. Preliminary calculations suggest that estimates of deadweight loss would be similar with a linear demand curve, but it would be useful in future analyses to more fully explore alternative functional forms.

Supply is assumed to be perfectly elastic. The infrastructure for transportation, refining, and distribution can be scaled up at near constant marginal cost, so what matters is the long-run supply elasticity for crude oil. This elasticity is extremely difficult to measure empirically, but in the long-run there clearly is a great deal of scope for global oil producers to respond to crude oil prices. This is particularly true with improved shale oil techniques and other emerging technologies that have opened up vast new production areas. Incorporating less than perfectly elastic supply would decrease the estimated global deadweight loss only modestly because fuel consumption in most countries is small relative to the world oil market.

Under these assumptions, the total global deadweight loss from fuel subsidies in 2012 is $\$ 44$ billion. This is split roughly evenly between gasoline ( $\$ 20$ billion) and diesel ( $\$ 24$ billion). Figure 3 reports deadweight loss by country. Saudi Arabia takes the top spot with $\$ 12$ billion in deadweight loss. Venezuela is number two with $\$ 10$ billion.

In 2012, Venezuela had the cheapest fuels on the planet so even though the total dollar value of subsidies is higher in Iran and Indonesia, the subsidies in Venezuela impose more economic cost because the subsidy per gallon is so high. Deadweight loss increases approximately with the square of the subsidy amount so it is extremely concentrated among countries with the very largest subsidies. The big two, Saudi Arabia and Venezuela, represent $50 \%$ of total global deadweight loss, while only representing $34 \%$ of the 


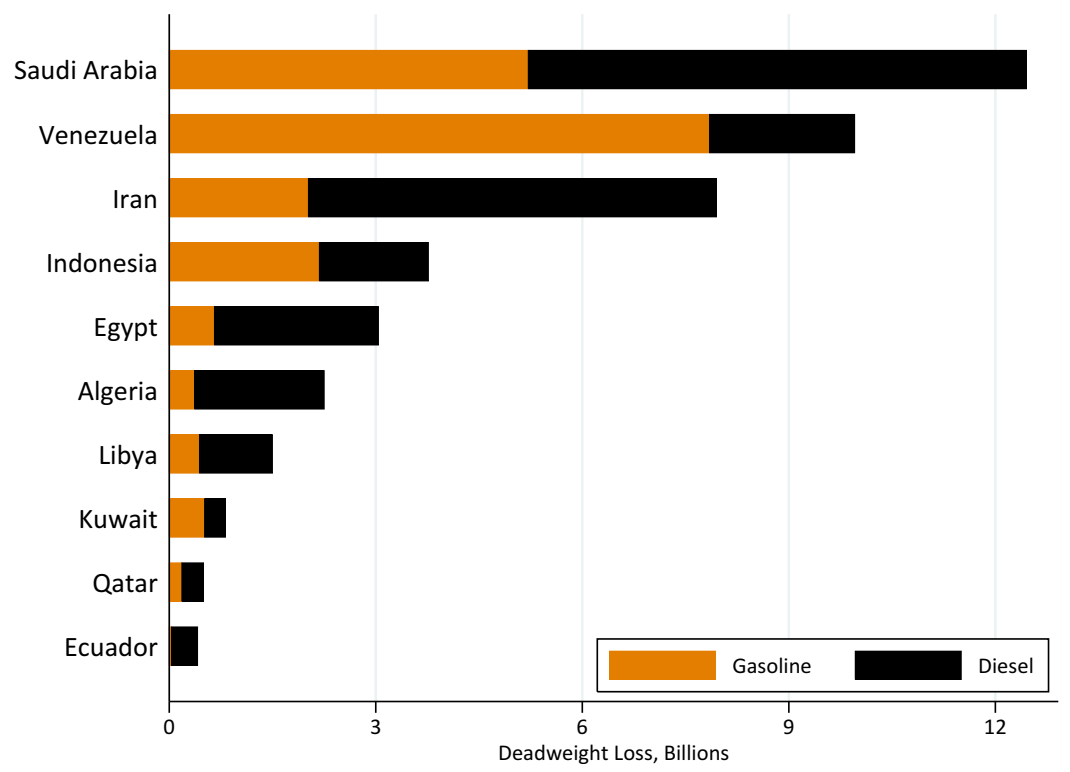

Figure 3: Deadweight Loss from Fuel Subsidies in 2012, Top Ten Countries

dollar value of subsidies.

When expressed per capita the pattern of deadweight loss is similar. Saudi Arabia remains in the top spot, with $\$ 450$ in annual deadweight loss per capita. Indonesia, Egypt, and Ecuador fall out of the top ten and are replaced with Bahrain, Brunei, and Oman. See the online appendix for details.

\section{$3 \quad$ Incorporating External Costs}

Fuel subsidies are different from subsidies in most other markets because of the substantial external costs. Parry et al. (2007) goes through the complete list, finding that marginal external damages are $\$ 1.11$ per gallon. Carbon dioxide emissions are an important component, but this also includes emissions of local pollutants, traffic congestion, and accidents. The $\$ 1.11$ per gallon also reflects that many externalities scale by miles traveled, rather 
than by gallons consumed, and so marginal external damages depend on the fraction of the demand elasticity that comes from reduced mileage.

Eliminating subsidies for gasoline and diesel would, with a -0.6 demand elasticity, decrease global fuel consumption by 29 billion gallons per year. At $\$ 1.11$ per gallon this excess consumption imposes external costs worth $\$ 32$ billion annually. Combined with the estimated deadweight loss ( $\$ 44$ billion), the total economic cost of fuel subsidies is $\$ 76$ billion annually. The global market for gasoline and diesel was $\$ 1.7$ trillion in 2012 , so this is $4 \%$ of the market.

This is the economic cost of pricing fuels below private cost. An alternative calculation would be to measure the deadweight loss relative to the full social cost of fuels consumption. This would include the deadweight loss ( $\$ 44$ billion) and external cost ( $\$ 32$ billion) from pricing below private cost, but also the additional welfare loss from units transacted for which willingness-to-pay is above private cost but below social cost. Deadweight loss under this counterfactual is $\$ 92$ billion.

Much of the increased deadweight loss in this alternative calculation comes from the United States, where gasoline and diesel prices are above private cost but below social cost. When ranked by country, the United States appears in spot number four, behind only Saudi Arabia, Venezuela, and Iran.

\section{Conclusion}

Previous studies have calculated the dollar value of global fuel subsidies (IEA (2012); IMF (2013)), but this paper goes one step further and calculates the economic cost. While undoubtedly these calculations could be refined substantially, the analysis makes it clear that fuel subsidies are not just benign transfers from sellers to buyers. Under reasonable assumptions about supply and demand elasticities, the economic cost of overconsumption is very large.

Fuel subsidies also have a large impact on government budgets, requiring taxes to be higher than they would otherwise, and inhibiting the ability 
of government to address other fiscal objectives. Expenditures on energy subsidies in many of these countries exceed public expenditures on health, education, and other key components of government spending. Understanding these fiscal impacts is an important priority for future work.

It will also be important to continue to study the distributional consequences of fuel subsidies. A recent set of international case studies finds that fuel subsidies are not particularly effective at redistribution (Sterner, ed, 2012), but more work is needed.

Finally, in future work it will be important to expand the analysis to include other energy markets. Fuel subsidies are only one part of a larger set of energy subsidies. Coal, natural gas, and electricity, for example, are all widely subsidized. Recent analyses of the broader energy sector find that the total dollar value of global energy subsidies is almost $\$ 500$ billion annually (IEA (2012); IMF (2013)) and much more can be done to understand and quantify the economic costs of these policies.

\section{References}

Aldy, Joe, "Eliminating Fossil Fuel Subsidies," The Hamilton Project, Innovative Approaches to Tax Reform, 2013.

Brons, Martijn, Peter Nijkamp, Eric Pels, and Piet Rietveld, "A Meta-Analysis of the Price Elasticity of Gasoline Demand: A SUR Approach," Energy Economics, 2008, 30, 2105-2122.

Gately, Dermot, Nourah Al-Yousef, and Hamad MH Al-Sheikh, "The Rapid Growth of Domestic Oil Consumption in Saudi Arabia and the Opportunity Cost of Oil Exports Foregone," Energy Policy, 2012.

Hamilton, James D., "Understanding Crude Oil Prices," Energy Journal, 2009, 30, 179-206.

International Energy Agency, "World Energy Outlook 2012," 2012.

International Monetary Fund, "Energy Subsidy Reform: Lessons and Implications," 2013. 
Knittel, Christopher R, "Reducing Petroleum Consumption from Transportation," Journal of Economic Perspectives, 2012, 26, 93-118.

Parry, Ian WH and Kenneth A Small, "Does Britain or the United States Have the Right Gasoline Tax?," The American Economic Review, 2005, 95 (4), 1276-1289.

_ , Margaret Walls, and Winston Harrington, "Automobile Externalities and Policies," Journal of Economic Literature, 2007, pp. 373-399.

Sterner, Thomas, ed., "Fuel Taxes and the Poor: The Distributional Effects of Gasoline Taxation and their Implications for Climate Policy," 2012 .

U.S. Department of Energy, Energy Information Administration, "International Energy Outlook," 2013.

World Bank, "World Development Indicators," http://data.worldbank.org/, 2013. 


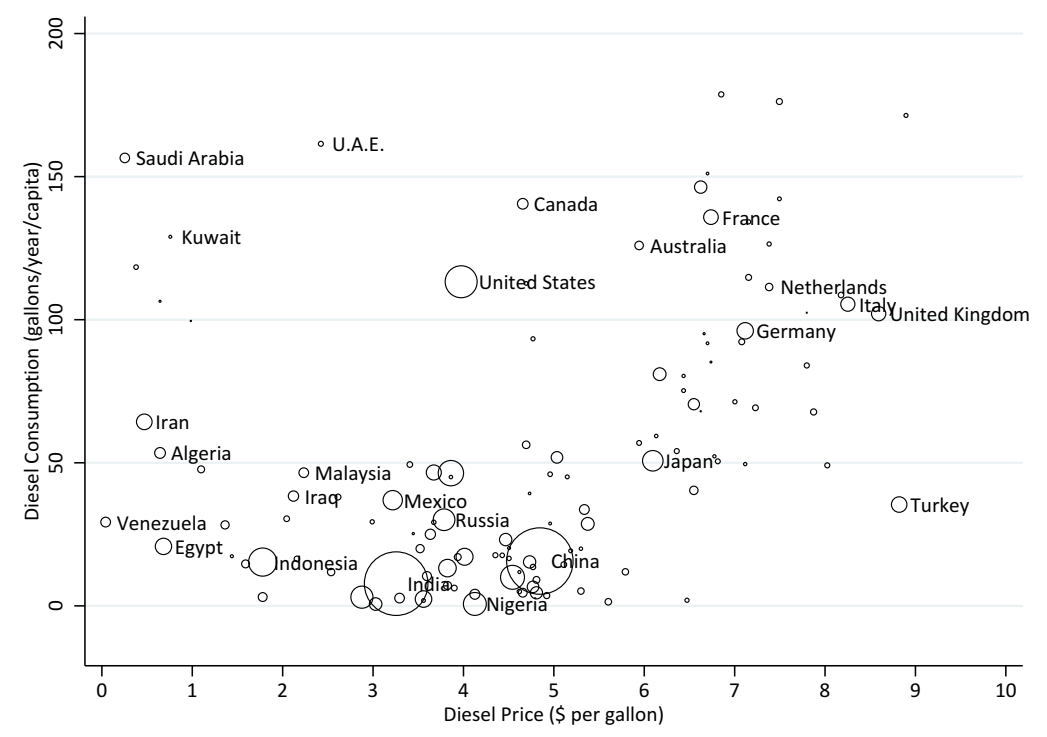

Figure A1: Diesel Consumption

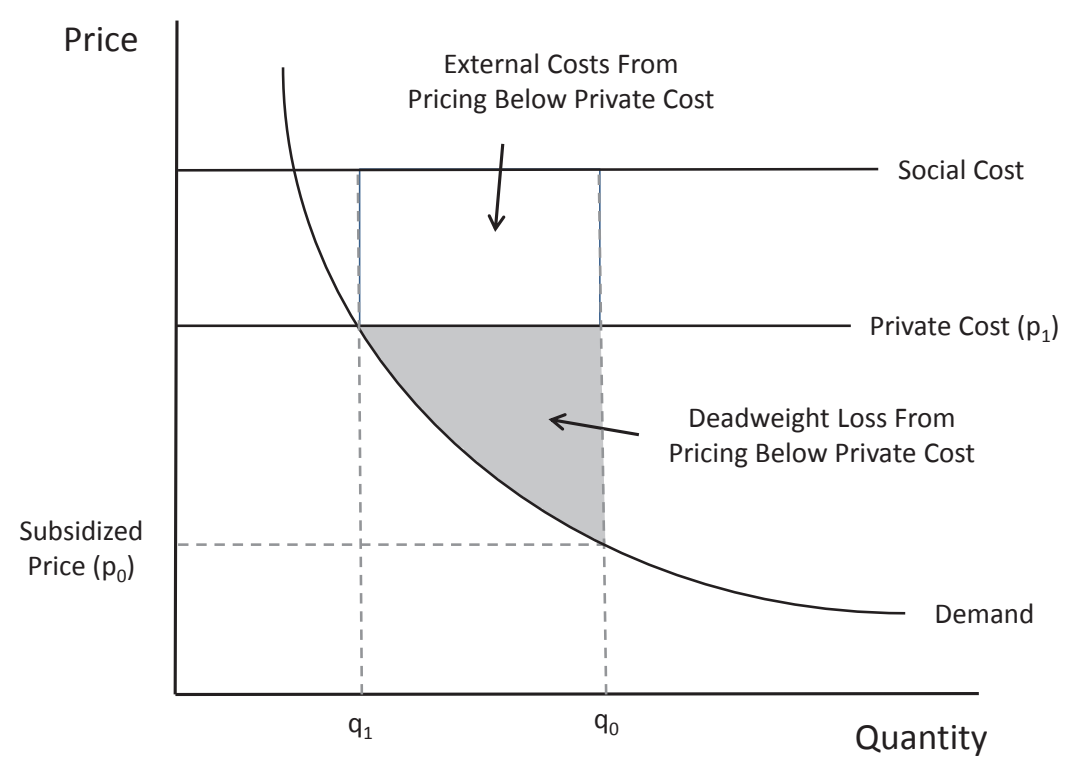

Figure A2: The Economic Cost of Fuel Subsidies 


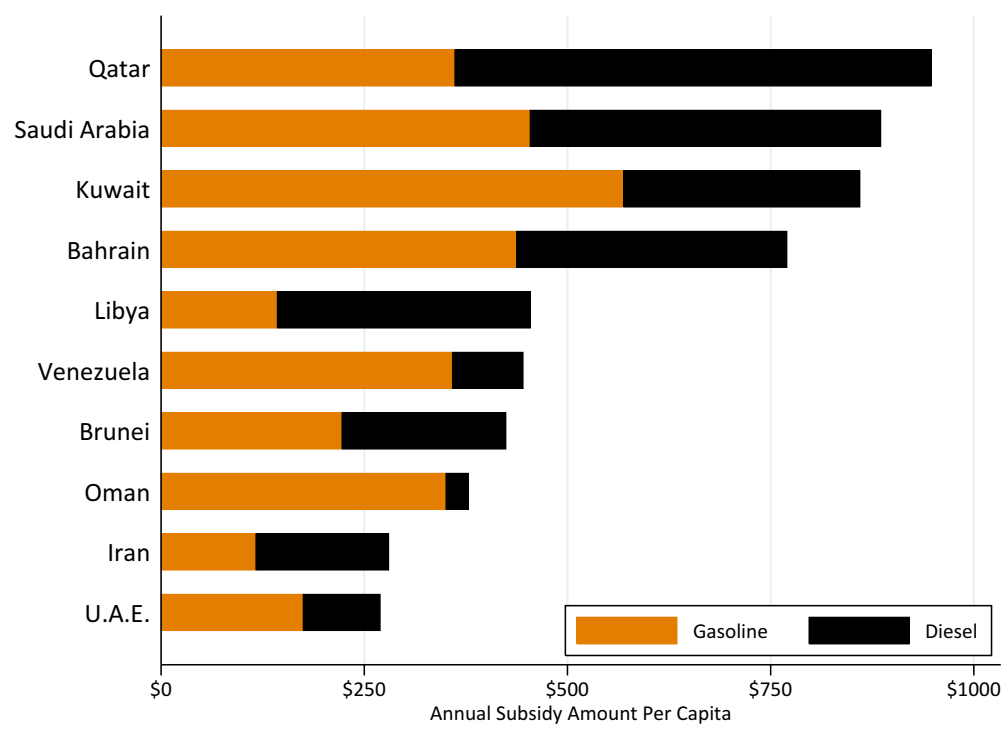

Figure A3: Fuel Subsidies Per Capita in 2012, Top Ten Countries

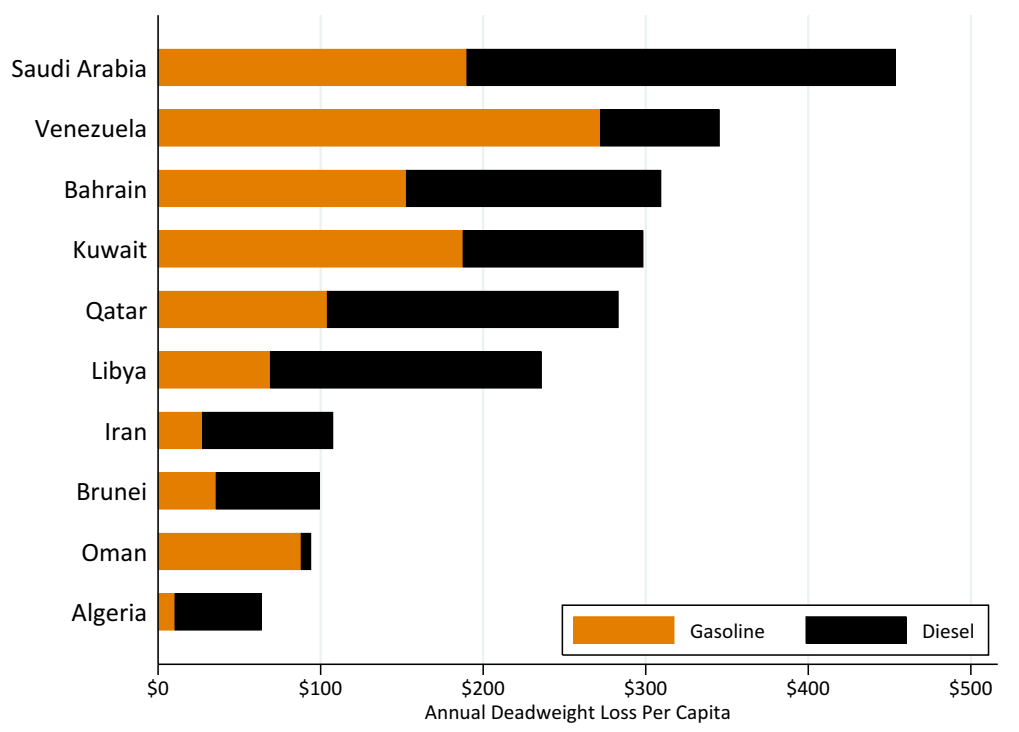

Figure A4: Deadweight Loss Per Capita in 2012, Top Ten Countries 


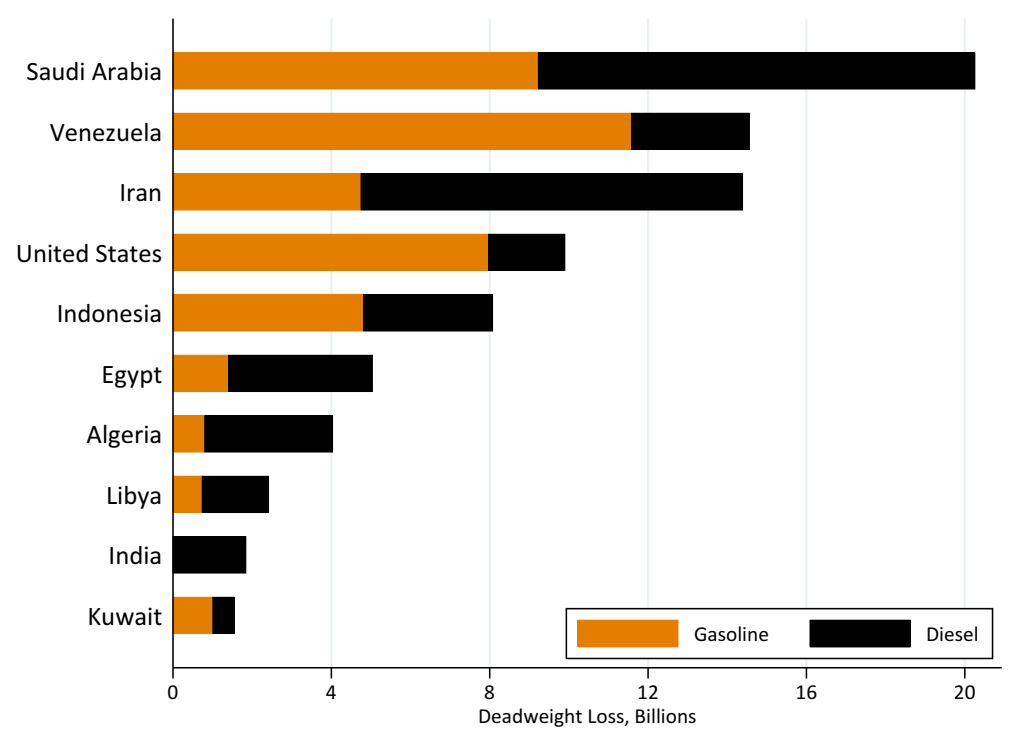

Figure A5: Deadweight Loss From Pricing Below Social Marginal Cost, Top Ten Countries 


\section{Not For Publication Appendix: Calculating Deadweight Loss}

Demand for gasoline and diesel are described using a constant elasticity demand function, $q=A p^{\epsilon}$ with a scale parameter $A$ that varies across countries and fuels, price $p$, and elasticity $\epsilon$. This demand function is used to predict consumption under market prices and to calculate deadweight loss. Let $p_{0}$ and $p_{1}$ denote the subsidized price and market price, respectively and let $q_{0}$ and $q_{1}$ denote consumption levels corresponding to those prices.

For an assumed demand elasticity, e.g., -0.6 , and observed consumption level at the subsidized price $q_{0}$ it is straightforward to calculate the scale parameter for a given country and fuel. The demand function can then be used to predict consumption at the market price.

Deadweight loss can be calculated as the shaded area in Figure A2. Start with the rectangle $\left(p_{1}-p_{0}\right) q_{0}$, and then substract off the area to the left of the demand curve between the subsidized price $p_{0}$ and market price $p_{1}$. This can be described with the following equation,

$$
D W L=\left(p_{1}-p_{0}\right) q_{0}-\int_{p_{0}}^{p_{1}} A p^{\epsilon} d p
$$

Evaluating the integral yields,

$$
D W L=\left(p_{1}-p_{0}\right) q_{0}-\frac{A}{(1+\epsilon)}\left[p_{1}^{(1+\epsilon)}-p_{0}^{(1+\epsilon)}\right] .
$$

Another, equivalent approach for calculating the same area is to start with the inverse demand function,

$$
p=\left(A^{-1} Q\right)^{1 / \epsilon}
$$

and calculate the area below the demand curve between $q_{0}$ and $q_{1}$, and then substract this from the rectangle $\left(q_{1}-q_{0}\right) p_{1}$,

$$
D W L=\left(q_{0}-q_{1}\right) p_{1}-\int_{q_{1}}^{q_{0}} A^{-\frac{1}{\epsilon}} q^{\frac{1}{\epsilon}} d q .
$$

Evaluating the integral yields,

$$
D W L=\left(q_{0}-q_{1}\right) p_{1}-A^{-\frac{1}{\epsilon}} \frac{1}{\eta}\left[q_{0}^{\eta}-q_{1}^{\eta}\right] .
$$


where $\eta=\frac{1}{\epsilon}+1$.

It is helpful to go through an example. In Saudi Arabia the price of gasoline $\left(p_{0}\right)$ in 2012 was $\$ 0.61$, and consumption $\left(q_{0}\right)$ was 5,637 million gallons. Rearranging the demand function to solve for $A$ yields,

$$
A=q_{0} p_{0}{ }^{-\epsilon}=5637 * 0.61^{0.6}=4190 .
$$

So at the market price $\$ 2.82$ the demand equation implies that consumption would be equal to,

$$
q_{1}=A p_{1}{ }^{\epsilon}=4190 * 2.82^{-0.6}=2241 .
$$

Thus this demand function implies that, in the long run, gasoline consumption would fall from 5,637 million gallons to 2,241 million gallons were prices to increase to $\$ 2.82$.

Using equation (1), deadweight loss is equal to,

$$
D W L=(\$ 2.82-\$ 0.61) * 5637-\frac{4190}{(0.4)}\left[\$ 2.82^{(0.4)}-\$ 0.61^{(0.4)}\right]=\$ 5195 .
$$

Or, $\$ 5.2$ billion in deadweight loss in the gasoline market for 2012 .

Using equation (2), deadweight loss is equal to, $D W L=(5637-2249) * \$ 2.82-4190^{\frac{-1}{-0.6}} \frac{1}{-2 / 3}\left[5637^{-2 / 3}-2241^{-2 / 3}\right]=\$ 5195$.

Or $\$ 5.2$ billion. As expected, both approaches yield the same measure for deadweight loss. 
Table A1: Deadweight Loss in 2012, Top Ten Countries By Fuel

\begin{tabular}{|c|c|c|c|c|}
\hline & $\begin{array}{c}\text { Price } \\
\text { per Gallon } \\
\text { (Nov 2012) }\end{array}$ & $\begin{array}{c}\text { Consumption } \\
\text { in } 2012 \\
\text { (millions of gallons) }\end{array}$ & $\begin{array}{c}\text { Predicted } \\
\text { Consumption at } \\
\text { Market Price } \\
\text { (millions of gallons) }\end{array}$ & $\begin{array}{c}\text { Deadweight } \\
\text { Loss } \\
\text { in } 2012 \\
\text { (billions) }\end{array}$ \\
\hline & (1) & $(2)$ & (3) & (4) \\
\hline \multicolumn{5}{|c|}{ Panel A. Gasoline } \\
\hline Venezuela & $\$ 0.09$ & 3786 & 470 & 7.8 \\
\hline Saudi Arabia & $\$ 0.61$ & 5637 & 2241 & 5.2 \\
\hline Indonesia & $\$ 1.78$ & 6002 & 3949 & 2.2 \\
\hline Iran & $\$ 1.25$ & 5505 & 3379 & 2.0 \\
\hline Egypt & $\$ 1.70$ & 1637 & 1050 & 0.7 \\
\hline Kuwait & $\$ 0.87$ & 801 & 396 & 0.5 \\
\hline Libya & $\$ 0.45$ & 385 & 129 & 0.4 \\
\hline Algeria & $\$ 1.10$ & 797 & 453 & 0.4 \\
\hline Oman & $\$ 1.17$ & 593 & 351 & 0.2 \\
\hline Bahrain & $\$ 1.02$ & 216 & 102 & 0.2 \\
\hline \multicolumn{5}{|c|}{ Panel B. Diesel } \\
\hline Saudi Arabia & $\$ 0.25$ & 4297 & 974 & 7.2 \\
\hline Iran & $\$ 0.47$ & 4757 & 1560 & 5.9 \\
\hline Egypt & $\$ 0.68$ & 1686 & 605 & 2.4 \\
\hline Venezuela & $\$ 0.04$ & 845 & 65 & 2.1 \\
\hline Algeria & $\$ 0.64$ & 1896 & 751 & 1.9 \\
\hline Indonesia & $\$ 1.78$ & 3674 & 2343 & 1.6 \\
\hline Libya & $\$ 0.38$ & 752 & 217 & 1.1 \\
\hline Ecuador & $\$ 1.10$ & 690 & 377 & 0.4 \\
\hline Qatar & $\$ 1.02$ & 519 & 271 & 0.3 \\
\hline Kuwait & $\$ 0.76$ & 353 & 154 & 0.3 \\
\hline
\end{tabular}

